\title{
BREEDING BIOLOGY OF BOOTED EAGLE Hieraaetus pennatus (Gmelin, JF, 1788): THE FIRST STUDY IN NORTH AFRICA
}

\author{
ISSAM BOUCHAHDANE ${ }^{1 *}$, MOHAMED BOUKHEMZA², KARIM SOUTTOU ${ }^{1}$, AREZKI \\ DERRIDJ $^{2}$
}

${ }^{1}$ Department of Agronomy, Faculty of Science of Nature and Life, University of Djelfa, 17000 Djelfa, Algeria; e-mail: ibouchahdan@gmail.com

${ }^{2}$ Earth Biology and Ecology Laboratory, Faculty of Biological and Agricultural Sciences, Mouloud Mammeri University of Tizi Ouzou, B.P. 17 R.P., DZ, 15000, Algeria

* Author for correspondence

\begin{abstract}
Bouchahdane I., Boukhemza M., Souttou K., Derridj A.: Breeding biology of booted eagle Hieraaetus pennatus (Gmelin, JF, 1788): the first study in North Africa. Ekológia (Bratislava), Vol. 38, No. 4, p. 382-391, 2019.

Knowledge and study of breeding birds' biology is essential to understand the dynamic, assess productivity and identify threats. The population of booted eagles (Hieraaetus pennatus) was studied during three consecutive breeding seasons (2013-2015) in the Chettabah forest. Each year, arrivals of Booted eagles are recorded during March (15 individuals in 2013, 12 in 2014 and 11 in 2015 ). For the three years of study, the mean breeding pair's density was $1.23 \pm 0.153 / \mathrm{km}^{2}$, incubation period ranged from 33 to 38 days, whilst the frequency distribution of clutch size was $67.6 \%$ for 2 eggs, $27 \%$ for 1 and $5.4 \%$ for 3 . Amongst the 63 eggs monitored, 55 hatched. No significant variation in hatching rate was observed during the 3 years (90\% in 2013, 76.19\% in 2014 and $84 \%$ in 2015). The comparison of breeding parameters with those reported in Spain showed a noticeable similarity. Further investigations should be conducted to improve the provision of information to support sound management interventions of this North African population.
\end{abstract}

Key words: booted eagle, paired density, breeding biology, forest, North Africa.

\section{Introduction}

Raptors are at the top of their food chain and are considered to be biologically important and environmentally sensitive (Olendorff et al., 1989) and ecosystem health indicators (Newton, 1979; Donázar et al., 2002; Sergio et al., 2005). They act as a conservation flagship (Simberloff, 1998).

The booted eagle is a summer resident in southern Europe, although some individuals winter in the Mediterranean Basin (Martínez, Sánchez-Zapata, 1999; Baghino et al., 2007). The booted eagle Aquila pennata is mainly a trans-Saharan migratory species, but some in- 
dividuals overwinter in Southern Europe and North Africa (Zalles, Bildstein, 2000; Thévenot et al., 2003).

The majority of the population migrates to tropical Africa through the Strait of Gibraltar and the Bosphorus (Cramp, Simmons, 1980). Migratory routes remain poorly known, with one study based on one individual tracked by satellite telemetry published to date (Chevallier et al., 2010). The booted eagle Hieraaetus pennatus is considered 'rare' in Europe, where it breeds in Western Europe (France, Portugal and Spain) and Eastern Europe (most of them in Russia, Turkey and Ukraine) with several thousands of couples (Garcia-Dios, 2014).

Very few biological aspects of the booted eagle are known, and this species is considered one of the least known of all European raptor (Suárez et al., 2000; Bosch et al., 2005). Although some scientific studies have been focused on the habitats (Suárez et al., 2000; Díaz, 2005; Martínez et al., 2007) in North Africa, studies on raptors, amongst them, the booted eagle, are rare, which are mostly conducted on distribution and inventories, and a few phenological studies are also conducted (Isenmann, Moali, 2000; Thévenot et al., 2003; Isenmann et al., 2005), but there was no work on raptors breeding biology, especially the booted eagle. The present work on the breeding of several pairs of the booted eagle in the mountain ranges of Constantinois (Algeria) provided the first contribution to the study of the breeding biology of this species in North Africa.

\section{Material and methods}

\section{Study area}

Field data were collected from the Chettabah forest $\left(24000 \mathrm{~h}\right.$ ), province of Constantine ( $36^{\circ} 18^{\text {'to }} 36^{\circ} 21^{\prime}$ ' N; $6^{\circ} 26$ 'and $6^{\circ} 30^{\prime} \mathrm{E}$ ), which is located in the centre East of Algeria, about $245 \mathrm{~km}$ from the Algerian-Tunisian borders, 431 $\mathrm{km}$ from the capital Algiers to the west, $89 \mathrm{~km}$ from Skikda to the north (the Mediterranean Sea) and $235 \mathrm{~km}$ from Biskra to the south (The Sahara).

The Chettabah forest is built on a majestic rock located on both sides of Oued Rhumel; it is thus surrounded by real natural obstacles; the landmarks show that the region is heterogeneous when it comes to its position and its sea level; the region is located at an altitude of $694-1350 \mathrm{~m}$ above sea level. The study area has a sub-humid and semiarid climate, with an average temperature varying between $8^{\circ}$ in winter and $34^{\circ}$ in summer, at an altitude of $694 \mathrm{~m}$. It is characterised by a very rugged terrain crisscrossed by several seasonal thalwegs and spread over all forests with the presence of numerous ridges (Belgherbi et al., 2018). Its vegetation is dominated by the Aleppo Pine, the Green Oak, the Atlas Pistachio and ). Its vegetation is dominated by the Aleppo Pine, the Green Oak, the Atlas Pistachio and the maquis shrublands are of low proportion. (Fig. 1).

\section{Field work}

This work was carried out for three consecutive breeding seasons (2013-2015) from the end of March until the end of September. We conducted a bi-monthly phenological monitoring and counting of the booted eagle in the Chettabah forest and a weekly monitoring and counting of breeding couples ( 2 times per week) in the the zouaoui cliff using binoculars $(90 * 90)$ and a telescope $(60 * 80)$ to locate the nests.

Once the nest is located, we noted the date of its discovery, its geolocation using a GPS (Global Positioning System ) (Garmin) and its height from the ground. The nest dimensions (internal diameter and external diameter) were recorded; we also measured the size of eggs (number of eggs per nest), the weight of the eggs using an electronic scale ( $0.01 \mathrm{~g}$ of accuracy) and their length (A) and width (B) using an electronic Vernier caliper.

Hoyet's (1979) formula $\mathrm{V}=0.51 \times \mathrm{A}$ x B2 allowed us to calculate the eggs volume. The two visits per week allowed us to estimate the incubation period (Del Hoyto et al., 1994) and also to monitor the hatching success (the ratio between the number of eggs laid and the number of hatched eggs) and fledging success, which translates to the 


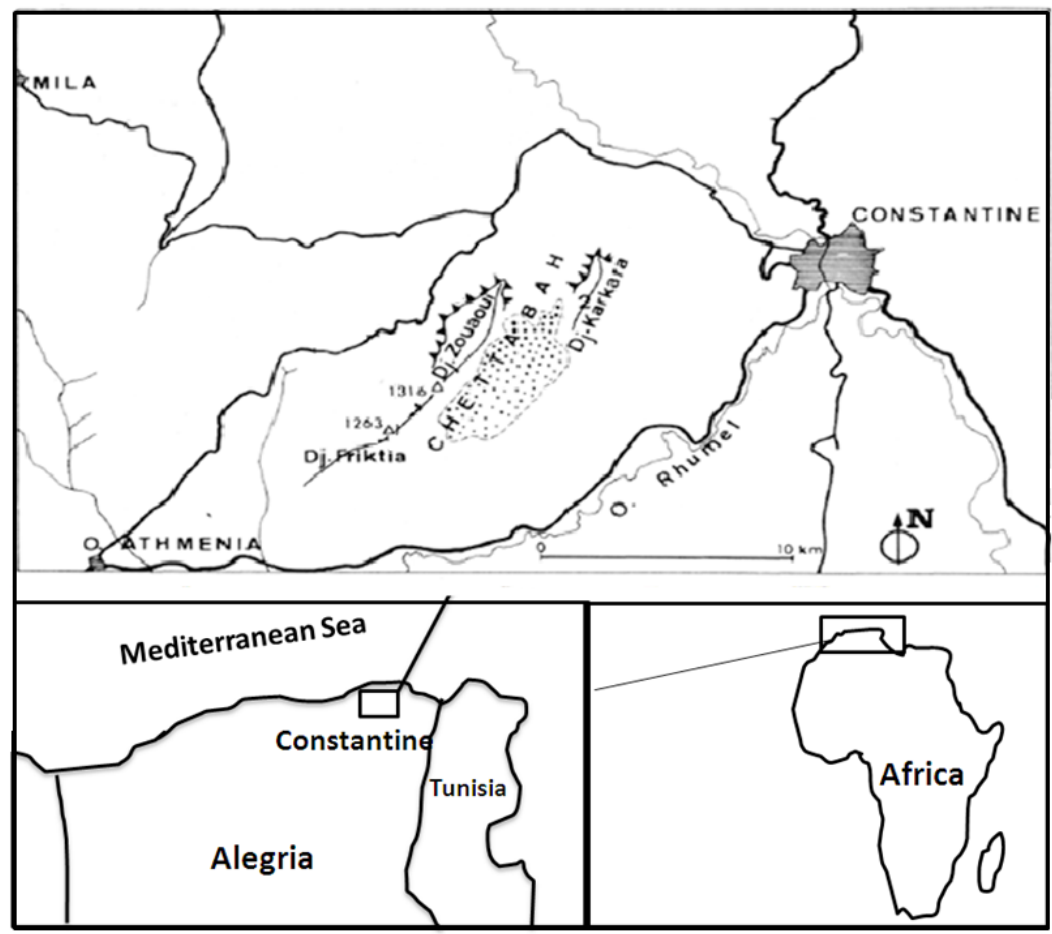

Fig. 1. Geographic location of the study area: Chettabah forest (Marre et al., 1977).

number of fledgling chicks per contribution to the number of eggs hatched (Martínez et al., 2006a). The flight rate was calculated by dividing the number of fledgling chicks by the total number of active nest (García-Dios, 2014). The nests that were inaccessible were followed using a binocular and a telescope to be able to note their clutch size, their hatching success and fledging success.

\section{Statistical analysis}

All analyses were performed after verification of normality criteria (Kolmogorov-Smirnov test) and homoscedasticity (Levene's test) of the different dependent and independent variables. The one-way ANOVA (Anlaysis of variance ) parametric test was performed to see if there is a 3-year variation in booted eagle abundance as well as nest and egg size and incubation period. Other non-parametric test such as the Kruskal-Wallis test was used to see if the variation depends on the years of hatching success and fledging success, and chi-squared test allowed us to evaluate the distribution of the clutch size according to the 3 years of monitoring. Statistical analyses were carried out using $\mathrm{R}$ ( $\mathrm{R}$ development core 2015).

\section{Results and discussion}

\section{Phenology, abundance and pairs density}

The population size of the booted eagles in the Chettabah forest remain stable during the 3 years of survey (ANOVA: $\mathrm{F}=0.551 ; \mathrm{df}=2 ; \mathrm{p}>0.05$ ) (Fig. 2). 
The booted eagle occupies the Chettabah forest for almost 7 months (from the end of March to the end of September). In this study, the booted eagle arrives in March every year with a large number of individuals (15 individual in 2013, 12 individual in 2014 and 11 individual in 2015). The population size reaches its first peak at the beginning of May with 28 individual in 2013, 35 individual in 2014 and 36 individual in 2015; however, it reaches its second peak at the end of August with a fairly large number of individuals (33 individual in 2013, 38 individual in 2014 and 42 individual in 2015; Fig. 3).

In Algeria, Isenmann et Moali (2000) reported that the species arrives in the middle of March and leaves at the end of September. Our

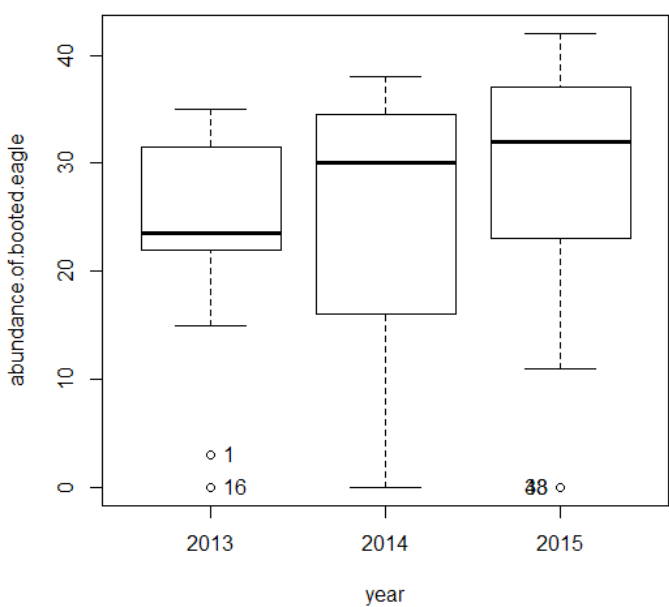

Fig. 2. Box plot representing the variation of booted eagle abundance amongst 3 years of monitoring. results are similar to those recorded in the south-west of the Mediterranean (south-east Spain) (Martínez et al., 2006b; JiménezFranco et al., 2014). In the Chettabah ravin , the number of pairs varied in the range of 11-14 pairs (11 pairs in 2013, 12 pairs in 2014 and 14 pairs in 2015), with a mean density of $1.23 \pm$ $0.153 / \mathrm{km}^{2}$. Our results are more important than those reported in the south of Spain, Murcia (ranked first site in Europe), with $1.29 \pm 0.3 / 10 \mathrm{~km}^{2}$ (Martínez et al., 2006b, 2011).

Garzón (1974): 1 pp./0.67 km² , Díaz Robledo (Martí, Del Moral, 2003): 11 pp./35 km² in the western portion of Malaga, Hiraldo and González Grande (1987): 1 pp./0.80 km² (minimum) and 1 pp./15 km² (maximum), Garcia Dios in Bosch ( 2003): 1 pp. $/ 3.20 \mathrm{~km}^{2}$ (Candeleda, Ávila) and 1 pp. $/ 2.03 \mathrm{~km}^{2}$ (valle del Tiétar, excepting Candeleda), Díaz (2006): 18 pp./10 km² (Madrid), In Mallorca there is an abundance of $0.048 \mathrm{pp}$. $/ \mathrm{km}^{2}$ and in Menorca $0.130 \mathrm{pp}$. $/ \mathrm{km}^{2}$ (Viada, de Pablo, 2009), Abundances have been recorded as 1 territory $/ 10 \mathrm{~km}^{2}$ in Murcia, 0.8 territories/10 $\mathrm{km}^{2}$ in Castellon, 0.7 territories $/ 10 \mathrm{~km}^{2}$ in extremadura, 0.7 territories $/ 10 \mathrm{~km}^{2}$ in Castile and León 0.6 territories $/ 10 \mathrm{~km}^{2}$ in Andalusia, Cantabria and la Rioja (Palomino, Valls, 2011).

Abundances have been recorded as 1 territory $/ 10 \mathrm{~km}^{2}$ in Murcia, 0.8 territories $/ 10 \mathrm{~km}^{2}$ in Castellon, 0.7 territories $/ 10 \mathrm{~km}^{2}$ in extremadura, 0.7 territories $/ 10 \mathrm{~km}^{2}$ in Castile and León 0.6 territories $/ 10 \mathrm{~km}^{2}$ in Andalusia, Cantabria and la Rioja (Palomino, Valls, 2011).

\section{Description of habitat and nest measurement}

A total of 37 nests were monitored, including 28 nests (75.67\%) for 3 consecutive years, 11 nests in 2013, of which 08 were measured; 12 nests in 2014, of which 10 were measured; 


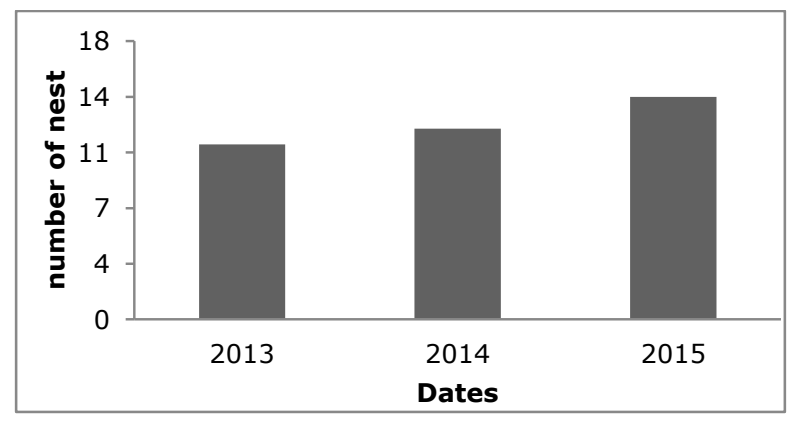

Fig. 3. Number of nests for booted eagle in forest of Chettabah amongst 3 years of monitoring. and 14 nests in 2015, of which 10 were measured. All the nests were built on branches of pistachio (67.56\%) and Aleppo pine $(32.43 \%)$ (Fig. 3). In Europe, the booted eagle builds its nest on several types of support (e.g. Pinus sylvestris (Díaz, 2005), $P$. pinaster (García-Dios, Viñuela, 2000), P. nigra (Díaz et al., 1994), Quercus suber (Urios et al., 1991), Fagus sylvatica (Iribarren, Rodríguez Arbeloa, 1988) and Eucalyptus eucalyptus (Suárez et

al., 2000). Our results are approximately similar to those announced by Martínez (2002) in Murcia and (Bosch, Prat, 2011) in Catalonia, where Pinus halepensis is the preferred support for the nesting of this species. The internal diameter of the nest varies between 20 and $46 \mathrm{~cm}$. The external diameter varies between 63 and $108 \mathrm{~cm}$; the height varies between 125 and 210 $\mathrm{m}$. All the measured parameters do not vary according to the 3 years of monitoring: internal diameter (ANOVA: $\mathrm{F}=3.171 ; \mathrm{df}=2 ; \mathrm{p}=0.055$ ), external diameter (ANOVA: $\mathrm{F}=2.347 ; \mathrm{df}$ $=2 ; \mathrm{p}=0.111$ ), height (ANOVA: $\mathrm{F}=2.311 ; \mathrm{df}=2 ; \mathrm{p}=0.115)$. Our results confirm what was proved by Zuberogoitia et al. (2011) in Spain (Bizkaia) (Table 1).

\section{Clutch size and egg measurement and period of incubation}

The clutch size varies between 1 and 2-3 eggs. The number of nests with a modal clutch size is 2 eggs (67.6\%), 1 egg (27\%) and 3 eggs (5.4\%) among the 3 years. The mean clutch size is $2.7 \pm 0.48$ in $2013,2.66 \pm 0.48$ in 2014 and $2.6 \pm 0.50$ in 2015. The distribution of this clutch size shows that there is no a significant difference amongst the 3 years $(\mathrm{X} 2=1.18$; $\mathrm{df}$ (degree of freedom $)=4 ; \mathrm{p}>0.05$; Fig. 4).

For most species, nest construction involves a considerable investment of time and energy that could be reallocated directly to reproduction if nests were reused, resulting pos-

T a b le 1. Comparison of booted eagle nest characteristics in North Africa (present study) and Southern Europe (Spain).

\begin{tabular}{|l|l|c|c|c|c|c|}
\hline \multirow{2}{*}{ Nests characteristics } & & Mean & Min & Max & SD & $\begin{array}{c}\text { Coefficient } \\
\text { of variation (\%) }\end{array}$ \\
\hline \multirow{3}{*}{ Present study $(\mathrm{n}=37)$} & Internal diameter $(\mathrm{cm})$ & 34.33 & 20 & 46.00 & 6.52 & 18.99 \\
\cline { 2 - 7 } & External diameter $(\mathrm{cm})$ & 82.33 & 63 & 108 & 11.82 & 14.35 \\
\cline { 2 - 7 } & Height of nests $(\mathrm{m})$ & 164.33 & 125 & 210 & 21.45 & 13.05 \\
\hline \multirow{3}{*}{ Spain (Zuberogoitia et al., 2011) } & Internal diameter $(\mathrm{cm})$ & 27.5 & - & - & - & - \\
\cline { 2 - 7 } & External diameter $(\mathrm{cm})$ & 72.5 & - & - & - & - \\
\cline { 2 - 7 } & Height of nests $(\mathrm{m})$ & - & - & - & - & - \\
\hline
\end{tabular}


sibly in earlier clutch initiation or larger clutch sizes (Redmond et al., 2007). Booted eagle clutch size varies between 1 and 2 eggs, and, rarely, 3 eggs (Martínez, 2002). Our results are similar to those found by Díaz Ruiz and Cebollada Baratas (2011) in Guadarrama Mountains (Spain) with a modal clutch size of 2 eggs (67\%), 1 egg (25\%) and 3 eggs (8\%) (Díaz Ruiz, Cebollada

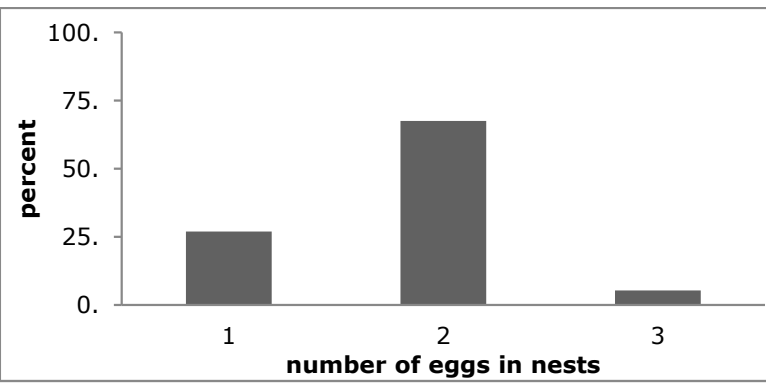

Fig. 4. Frequency distribution of clutch size of booted eagle in North Africa during the 3 years of study. Baratas, 2011).

In the total of 63 eggs, 49 eggs were measured, of which egg length does not vary significantly amongst 3 years of monitoring (ANOVA: $\mathrm{F}=0.148 ; \mathrm{df}=2 ; \mathrm{p}>0.05$ ).

The length of the eggs varies between 50.78 and $58.20 \mathrm{~mm}$ during the 3 years of monitoring, with an average of $63.60 \pm 2.09 \mathrm{~mm}$ in 2013, $54.97 \pm 1.61 \mathrm{~mm}$ in 2014 and $54.69 \pm 2.36$ $\mathrm{mm}$ in 2015.

No significant difference was observed in the eggs width amongst the 3 years (ANOVA: $F$ $=2.016 ; \mathrm{df}=2 ; \mathrm{p}>0.05)$. Egg width varies between 40.32 and $49.12 \mathrm{~mm}$, with an average of $55.59 \pm 1.86 \mathrm{~mm}$ in $2013,54.91 \pm 1.66 \mathrm{~mm}$ in 2014 and $56.95 \pm 2.43 \mathrm{~mm}$ in 2015 .

No significant difference was observed in the weight of the booted eagle's eggs amongst the 3 years (ANOVA: $\mathrm{F}=0.842 ; \mathrm{df}=2 ; \mathrm{p}>0.05$ ). The weight of the eggs varies between 54 and $73.40 \mathrm{~g}$, with an average of $66.51 \pm 4.85 \mathrm{~g}$ in $2013,64.28 \pm 6.3 \mathrm{~g}$ in $201466.07 \pm 4.18 \mathrm{~g}$ in 2015. As for egg volume, it differs significantly among the years (Kruskal-Wallis test: X2 = $6.53, \mathrm{p}<0.05)$.

Numerous studies have shown that egg size is an important variable in the history of life and it influences survival and reproductive success (Thomas, 1983; Stokland, Amundsen, 1988; Rutkowska, Cichon, 2005). Our eggs biometric dimensions are similar to what has been confirmed in Spain (García Dios, unpublished data, The Booted Eagle book in Spanish) (Table 2).

T a b l e 2. Comparison of booted eagle's nest sizes in North Africa (present study) and Southern Europe (Spain).

\begin{tabular}{|l|c|c|c|c|c|c|}
\hline \multirow{2}{*}{ Eggs characteristics } & & Mean & Min & Max & SD & $\begin{array}{c}\text { Coefficient of } \\
\text { variation (\%) }\end{array}$ \\
\hline \multirow{3}{*}{$\begin{array}{l}\text { Present study } \\
(\mathrm{n}=49)\end{array}$} & Length $(\mathrm{mm})$ & 54.7665 & 50.78 & 58.2 & 2.01027 & 3.67 \\
\cline { 2 - 7 } & Width $(\mathrm{mm})$ & 44.1763 & 40.32 & 49.12 & 2.06441 & 4.66 \\
\cline { 2 - 7 } & Weight $(\mathrm{g})$ & 65.5898 & 54 & 73.4 & 5.18752 & 7.89 \\
\hline \multirow{2}{*}{\begin{tabular}{l} 
Spain $\begin{array}{l}\text { Garcia dios } 2014 \\
(\mathrm{n}=113)\end{array}$ \\
\cline { 2 - 7 }
\end{tabular}} & Length $(\mathrm{mm})$ & 54.73 & - & - & - & - \\
\cline { 2 - 7 } & Width $(\mathrm{mm})$ & 44.26 & - & - & - & - \\
\hline
\end{tabular}


The eggs are incubated by the female eagle during a period that varies between 33 and 38 days. No significant difference was observed in the incubation period amongst the 3 years of monitoring (ANOVA: $\mathrm{F}=0.200 ; \mathrm{ddl}=2 ; \mathrm{p}>0.05$ ). Incubation is an essential part of breeding birds (Deeming, 2002). It is an energetically costly step, and it takes time in the breeding cycle (Vleck, 1981a,b; Reid et al., 2002). Our results confirm what has been proved by various studies that the incubation period of the booted eagle eggs varies between 35 and 38 days (Iribarren, 1975; Cramp, Simmons, 1980; Bezzel, 1985; Iribarren, Rodríguez, 1988; Perrins, 1987; Del Hoyto et al., 1994; Martínez et al., 2005).

\section{4-success and mortality rate}

In the total of 63 eggs, 55 eggs were hatched, with an average of $54.22 \pm 2.36(90 \%)$ in 2013 , $54.11 \pm 2.88(76.19 \%)$ in 2014 and $51.77 \pm 2.04$ (84\%) in 2015. No significant difference was observed in the hatching success in functions of the 3 monitoring years (Kruskal-Wallis test: $\mathrm{X} 2=0.570, \mathrm{p}>0.05)$. The average number of fledglings is $52.69 \pm 2.15(88.88 \%)$ in 2013 , $73.38 \pm 2.73(87.50 \%)$ in 2014 and $54.69 \pm 2.36(85.71 \%)$ in 2015 . The number of fledging was not significantly variable amongst the years of study (Kruskal-Wallis test: X2 $=0.040 ; \mathrm{p}>$ 0.05). Our results regarding hatching success and fledged success are close to what have been proved by Martínez et al. (2006a,b and 2011) in Spain (Table 3).

The fledgling chick/nest number is 1.297 chicks $(n=37)$ is close to $S^{a}$ de Guadarrama, 1.20 chick (Díaz, 2006); is important in Valle del Tiétar, 1.02 chicks (García Dios, Viñuela, 2000); and less important to southern Spain and northeastern Spain: Madrid, 1.46 (Díaz, 2006) and Murcia, 1.57 chick (Sánchez et al., 1995) and 1.65 chick (Martinez et al., 2006a). Alto Tajo: 1.70 chick (Arroyo, 2003), Central Catalonia: 1.82 chick (Bosch, 2003) and North $S^{a}$ : 1.72 chick (Díaz, 2006). The mortality rate is $11.11 \%$ (2013), $12.50 \%$ (2014), $17.64 \%$ (2015) of an average $13.752 \%$ during the study years, (Martínez et al., 2006a) suggested that, The main cause of mortality is predation by carnivores and owls. In our study area, owls were noticed by regurgitation pellets as well by their nocturnal scream, which can be one of the causes of loss of chicks throughout the study period. Our results are significant in contribution to those announced at Téitar Valley with a rate of 30.3\% (García Dios, Viñuela, 2000).

T a b l e 3. Comparison of booted eagle's nest success in North Africa (present study) and Southern Europe (Spain).

\begin{tabular}{|l|c|c|c|c|}
\hline \multirow{4}{*}{ Present study } & Year & $\begin{array}{c}\text { Number of } \\
\text { eggs laid }\end{array}$ & $\begin{array}{c}\text { Number of } \\
\text { eggs hatched (\%) }\end{array}$ & $\begin{array}{c}\text { Number of } \\
\text { young fledged (\%) }\end{array}$ \\
\hline & 2013 & 20 & 90 & 88.88 \\
\cline { 2 - 5 } & 2014 & 21 & 76.19 & 87.50 \\
\cline { 2 - 5 } & 2015 & 25 & 84 & 85.71 \\
\hline \multirow{5}{*}{ Spain (Martínez, 2006, 2011) } & 2002 & 24 & $20(81)$ & $19(95)$ \\
\cline { 2 - 5 } & 2003 & 27 & $22(81)$ & $18(82)$ \\
\cline { 2 - 5 } & 2004 & 33 & $24(73)$ & $13(54)$ \\
\cline { 2 - 5 } & 2007 & - & $18(90)$ & $9(90)$ \\
\cline { 2 - 5 } & 2008 & - & $17(68)$ & $12(86)$ \\
\cline { 2 - 5 } & 2009 & - & $24(73)$ & $15(83)$ \\
\hline
\end{tabular}




\section{Conclusion}

From this study, which turns out to be the first in North Africa, we were able to shed some light on the breeding biology of booted eagles in Algeria. Although pioneering, this work must be developed further in the near future. Indeed, certain aspects of the bioecology of this raptor deserve special attention to allow improving our understanding on the mechanisms driving this population. It would be, therefore, of great importance to initiate studies on multiscale factors (local versus landscape) affecting (i) the nest site selection, (ii) breeding parameters and (iii) nest survival.

\section{References}

Arroyo, B. (2003). Censo de rapaces forestales en el Parque Natural del Alto Tajo. Bioma TBC y Consejería de Medio Ambiente de Castilla-La Mancha. Informe inédito.

Baghino, L., Bottero, M., Pedemonte, R. \& Rapetti C. (2007). La migrazione post-nuziale dell'Aquila minore ad Arenzano nel 2006. Il Biancone, 2, 22-26.

Belgherbi, B., Benabdeli, K. \& Mostefai K. (2018). Mapping the risk of forest fires in Algeria: application of the forest of Guetarnia in western Algeria. Ekológia (Bratislava), 37(3), 289-300. DOI: 10.2478/eko-2018-0022.

Bezzel, E. (1985). Kompendium der Vögel Mitteleuropas. Nonpasseriformes. Wiesbaden: Aula-Verlag.

Bosch, J. (2003). Fenología y parámetros reproductivos del Aguililla Calzada Hieraaetus pennatus en Cataluña central (España). Ardeola, 50(2), 181-189.

Bosch, J., Borras, A. \& Freixas J. (2005). Nesting habitat selection of booted eagle Hieraaetus pennatus in Central Catalonia. Ardeola, 52(2), 225-233.

Bosch, J. (2011). Population and breeding ecology of booted eagle in Catalonia. In I. Zuberogoitia \& J.E. Martínez (Eds.), Ecology and conservation of European forest-dwelling raptors (pp. 87-92). Bilbao: Diputación Foral de Bizkaia.

Chevallier, D., Handrich, Y., Georges, J-Y., Baillon, F., Brossault, P., Aurouet, A., Le Maho, Y. \& Massemin S. (2010). Influence of weather conditions on the flight of migrating Black storks. Proc. R. Soc. Lond. B, 277, 2755-2764. DOI: $10.1098 / \mathrm{rspb} .2010 .0422$.

Cramp, S. \& Simmons K.E.L. (1980). Handbook of the birds of Europe, the Middle East and North Africa. Vol. 2. Hawks to Bustards. Oxford: Oxford University Press.

Deeming, D.C. (2002). Patterns and significance of egg turning. In D.C. Deeming (Ed.), Avian incubation: behaviour, environment and evolution (pp. 161-178). Oxford: Oxford University Press.

Del-Hoyo, J., Elliot, A \& Sargatal J. (Eds.) (1994). Handbook of the birds of the World. Vol. 2. New World Vultures to Guineafowl. Spain: Lynx Edicions.

Díaz, J. (2005). La vida privada del águila calzada. Quercus, 227, 14-21.

Díaz, J. ( 2006). El Águila Calzada y su conservación en la Comunidad de Madrid. Fondo para la Investigación y Conservación de los Animales Salvajes y su Hábitat FICAS. Madrid.

Díaz, M., Martí, R., Gómez-Manzaneque, Á. \& Sánchez A. (Eds.) (1994). Atlas de las Aves nidificantes en Madrid. Sociedad Española de Ornitología y Agencia de Medio Ambiente, Comunidad de Madrid.

Díaz-Ruiz, J. \& Cebollada Baratas F. (2011). Monitoring and conservation of the booted eagle Aquila pennata in the Sierra de Guadarrama (central Espaňa). In I. Zuberogoitia \& J.E. Martínez (Eds.), Ecología y Conservación de las Rapaces Forestales Europeas (pp. 93-98). Bilbao: Diputación Foral de Bizkaia.

Donázar, J.A., Blanco, G., Hiraldo, F., Soto-Largo, E. \& Oria J. (2002). Effects of forestry and other land- use practices on the conservation of cinereous vultures. Ecol. Appl., 12, 1445-1456. DOI: 10.1890/1051-0761.

García-Dios, I.S. \& Viñuela J. (2000). Efectos de la gestión forestal sobre el éxito reproductor del Aguililla Calzada (Hieraaetus pennatus) en el valle del Tiétar. Ardeola, 47, 183-190.

García-Dios, I.S. (2003). Siblicide and cannibalism in the Booted Eagle (Hieraaetus pennatus) in the Tietar valley, Central Spain. Journal of Raptor Research, 37(3), 261.

García-Dios, I.S. (2014). Booted Eagle (Hieraaetus pennatus). In A. Salvador \& M.B. Morales (Eds.), Enciclopedia Virtual de los Vertebrados Españoles. Madrid: Museo Nacional de Ciencias Naturales. 
Garzón, J. (1974). Contribución al estudio del status, alimentación y protección de las falconiformes en España central. Ardeola, 19, 279-330.

Hiraldo, F. \& González Grande J.L. (1987). Las Rapaces Ibéricas. Madrid: Centro de Fotografía de la Naturaleza.

Hoyt, D.F. (1979). Practical methods of estimating volume and fresh weight of bird eggs. The Auk, 96, 73-77. DOI: 10.1093/auk/96.1.73.

Iribarren, J.J. (1975). Biologia del Aguila calzada (Hieraaetus pennatus) durante el periodo de nidificacion en Navarra. Ardeola, 21, 305-320.

Iribarren, J.J. \& Rodríguez A.A. (1988). Sobre la biología del Águila Calzada Hieraaetus pennatus (Gmelin, 1788) en Navarra. Publicaciones de Biologia de la Universidad de Navarra, Serie Zoologicay, 17, 3-27.

Isenmann, P. \& Moali A. (2000). Oiseaux d'Algérie. Paris: SEOF.

Isenmann, P., Gaultier, T., El Hili, A., Azafzaf, H., Dlensi, H. \& Smart M. (2005). Birds of Tunisia. Paris: Société d'Etudes Ornithologiques de France.

Jiménez-Franco, M.V., Martínez, J.E. \& Calvo J.F. (2014). Patterns of nest reuse in forest raptors and their effects on reproductive output. J. Zool., 292(1), 64-70. DOI: 10.1111/jzo.12085.

Marre, A., Quinif, Y., Lahondere, J.C. \& Vila J.M. (1977). Le relief karstique et la géologie du versant Nord du Djebel Zouaoui (Constantine, Algérie). Méditerranée, 29(2), 45-54.

Martí, R. \& Del-Moral J.C. (Eds.) (2003). Atlas de las Aves Reproductoras de España. Dirección General de la Conservación de la Naturaleza. Madrid : Sociedad España de Ornitología.

Martínez, J.E. \& Sanchez-Zapata J.A. (1999). Invernada de aguililla calzada (Hieraaetus pennatus) y culebrera europea (Circaetus gallicus) en España. Ardeola, 46, 93-96.

Martínez, J.E., Pagán, I. \& Calvo J.F. (2006a). Factors influencing territorial occupancy and reproductive output in the Booted Eagle (Hieraaetus pennatus). Ibis, 148(4), 807-819. DOI: 10.1111/j.1474-919X.2006.00586.x.

Martínez, J.E., Pagán, I. \& Calvo J.F. (2006b). Interannual variations of reproductive parameters in a booted eagle (Hieraaetus pennatus) population: the influence of density and laying date. Journal of Ornithology, 147(4), 612-617. DOI: 10.1007/s10336-006-0086-0.

Martínez, J.E., Pagán, I., Palazón, J.A. \& Calvo J.F. (2007). Habitat use of booted eagles (Hieraaetus pennatus) in a Special Protection Area: implications for conservation. Biodivers. Conserv., 16, 3481-3488. DOI: 10.1007/ s10531-006-9053-6.

Martínez, J.E., Pagán, I., Jiménez-Franco M.V. \& Calvo J.F. (2011). Ecology of the booted eagle in semiarid Mediterranean landscapes. In I. Zuberogoitia \& J.E. Martínez (Eds.), Ecology and conservation of European forestdwelling raptors (pp. 226-233). Bilbao: Diputación Foral de Bizkaia.

Martínez, J.F. (2002). Ecologíadel Águila Calzada (Hieraaetus pennatus) en ambientes mediterráneos. Tesis Doctoral, Universidad de Murcia, Spain.

Newton, I. (1979). Population ecology of raptors. Berkhamsted: T. and A.D. Poyser.

Olendorff, R.S., Bibles, D.D., Dean, J.R., Haugh, J.R. \& Kochert M.N. (1989). Raptor habitat management under the U.S. Bureau of Land Management Multiple-use Mandate. Raptor Research Reports, 8, 1-80.

Palomino, D. \& Valls J. (2011). Las rapaces forestales en España. Población reproductora en 2009-2010 y método de censo. Madrid: Seo/BirdLife.

Perrins, C.H. (1987). Birds of Britain and Europe. London: HarperCollins.

Redmond, L.J., Murphy, M.T. \& Dolan A.C. (2007). Nest reuse by Eastern Kingbirds: adaptive behavior or ecological constraint? Condor, 109(2), 463-468. DOI: 10.1650/0010-5422(2007)109[463:NRBEKA]2.0.CO;2.

Reid, J.M., Monaghan, P. \& Nager R.G. (2002). Incubation aviaire: écologie, évolution et énergétique (éd DCDeeming) (pp. 314-325). Oxford: Oxford University Press.

Rutkowska, J. \& Cichon M. (2005). Egg Size, Offspring Sex and Hatching Asynchrony in Zebra Finches Taeniopygia guttata. J. Avian Biol., 36(1), 12-17. DOI: 10.1111/j.0908-8857.2005.03469.x.

Sánchez-Zapata, J.A., Sánchez, M.A., Calvo, J.F. \& Esteve M.A. (1995). Ecología de las Aves de Presa de la Región de Murcia. Murcia: Servicio de Publicaciones de la Universidad de Murcia.

Sergio, F., Newton, I. \& Marchesi L. (2005).Top predators and biodiversity. Nature, 436, 192-192. DOI: 10.1038/436192a.

Simberloff, D. (1998). Flagships, umbrellas and keystones: Is single-species management passe in the landscape era? Biol. Conserv., 83, 247-257. DOI: 10.1016/S0006-3207(97)00081-5.

Stokland, J.N \& Amundsen T. (1988). Initial size hierarchy in broods of the shag: Relative significance of egg size and hatching asynchrony. The Auk, 105, 308-315. DOI:10.2307/4087495.

Suárez, S., Balbontín, J. \& Ferrer M. (2000). Nesting habitat selection by booted eagles Hieraaetus pennatus and implications for management. J. Appl. Ecol., 37, 215-223. DOI: 10.1046/j.1365-2664.2000.00503.x. 
Thévenot, M., Vernon, R. \& Bergier P. (2003). The birds of Morocco (an annotated checklist). BOU.

Thomas, C.S. (1983). The relationship between breeding experience, egg volume and reproductive success of the kittiwake Rissa tridactyla. Ibis, 125, 567-574. DOI: 10.1111/j.1474-919X.1983.tb03151.x.

Urios, V., Escobar, J.V., Pardo, R. \& Gómez J.A. (1991). Atlas de las Aves nidificantes de la Comunidad Valenciana. Valencia: Conselleria d'Agricultura i Pesca. Generalitat Valenciana.

Viada, C. \& De-Pablo F. (2009). Cens d’aguila Calçada Hieraaetus pennatus a Balears al 2009 i estat de Conservacio). Anuari Ornitologic de les Balears, 24, 1-15.

Vleck, C.M. (1981a). Energetic cost of incubation in the Zebra Finch. Condor, 83, 229-237. DOI: 10.2307/1367313.

Vleck, C.M. (1981b). Hummingbird incubation : female attentiveness and egg temperature. Oecologia, 51(2), 199-205. DOI: 10.1007/BF00540601.

Zalles, J.I. \& Bildstein K.L. (Eds.) (2000). Raptor Watch: A global directory of raptor migration sites. Birdlife Conservation Series No. 9. Cambridge: Birdlife International, Kempton: Hawk Mountain Sanctuary.

Zuberogoitia, I., Castillo, I., Zabala, J., Iraeta, A. \& Azkona A. (2011). Population trends of diurnal forest raptors in Biscay. In I. Zuberogoitia \& J.E. Martínez (Eds.), Ecology and conservation of European forest-dwelling raptors (pp. 70-80). Bilbao: Diputación Foral de Bizkaia. DOI: 10.13140/2.1.2204.5121. 